\title{
Assessment of Landslides Susceptibility in Giri Watershed, Northwest Himalaya, Himachal Pradesh, India
}

\author{
Raghuveer Negi ${ }^{1 *}$ • Saraswati Prasad $\operatorname{Sati}^{2}$ • Deepak Kumar ${ }^{1}$ Sanjay Singh Rana ${ }^{1}$ \\ ${ }^{1}$ Department of Geology, DBS (PG) College Dehradun (Uttarakhand) \\ ${ }^{2}$ Department of Basic and Social Sciences, College of Forestry, Ranichouri, Tehri Garhwal, Garhwal U.K. \\ (VCSGUUHF Bharsar, Pauri Garhwal) \\ ${ }^{3}$ Department of geology, School of Earth Science, HNB Garhwal (Central) University, Srinagar (Garhwal) \\ Uttarakhand \\ *Corresponding author mail: raghuveer750@gmail.com
}

Received: 15.02.2021; Revised: 03.05.2021; Accepted: 12.05.2021

CSociety for Himalayan Action Research and Development

\begin{abstract}
The slope instability in the Himalayan terrain is a common phenomenon which is caused by a combination of the ongoing seismicity and climate variability (extreme weather evets). In addition to this, in the last few decades, the anthropogenic intervention in the form of various developmental activity (roads, hydropower projects, expansion of urban sectors etc.) have posed serious threat to slope stability. In this study we have evaluated the terrain status for landslide susceptibility in a monsoon fed Giri Watershed. An attempted has been made to decouple various causative factors of landslides susceptibility of the region using remote sensing and GIS techniques. Employing the Frequency ratio and the information value methods, the study observe that increasing incidences of landslides occur along the drainage in the lower valley sides, along the linear developmental activities and settlement areas. Further the study observed a broad correlation between rock formation, lineaments, vegetation types, and slope steepness.
\end{abstract}

Keywords: Landslides susceptibility $\bullet$ Frequency ratio methods $\bullet$ Information value methods $\bullet$ Remote sensing $\bullet$ Giri Watershed • Northwest Himalaya

\section{Introduction}

Himalayan eco-system is known for its inherent vulnerability that is attributed to its evolutionary history. Continental-continental collision caused by northward drifting Indian plate gave rise to this youngest and loftiest mountain chain (Dewey and Bird 1970; Dewey and Burke 1973). Compression is still going on and accumulated stress is occasionally released in the form of earthquake shocks (Yin 2006; DeMets et. al.1994; Singh et al. 2002).). Innumerable earthquake visits the Himalaya which made the terrain highly vulnerable and superimposed on the natural vulnerability, the human intervention particularly, changes in the land use land cover pattern over the last couple of decades have aggravated the already over pressurized eco-system. One of the major threats to the Himalayan ecosystem and its inhabitants are the landslides which every year impact the various infrastructures. Although the whole Himalayan ranges are prone to landslides, however, situation become worse in the watersheds that are located in the vicinity of major boundary thrusts. Landslide involves downward and outward movements of slope-forming 
materials due to gravitational force by a variety of motions like falling, sliding, flowing and any combination of the above (Cruden and Varnes, 1996). Enormous researches on the slope stability in precarious Himalayan terrain have been undertaken (e.g. Sati et al., 1998; Sarkar and Kanungo, 2004; Sati et.al., 2011; Devkota et al., 2013; Kanungo and Sharma, 2014; Sundriyal et.al., 2015; Kundu et al., 2017; Kumar et al., 2017; Sah et al., 2018). The consequences of landslides became much hazardous if they occur along the roads or across the lower order streams because they not only disrupt the much-required connectivity (if roads are involved), but impound the streams causing temporary blockades. Breaching of such blockades gives rise to high magnitude flash floods also called as the Landslide induced Lake outburst floods (LLOFs) (Rana et al., 2007). Over the last couple of decades, incidences of cloudburst leading to flash floods and landslides are showing an increasing trend. Himachal Pradesh endowed with rich biodiversity and sustain one of the highly profitable tourism industries but also highly evolved horticulture in the country particularly grown on the precariously stabilized slopes on the lesser and Higher Himalaya. Aided to this is the growing pressure of human settlements which is impacting the natural resource base thus adversely augmenting the terrain sustainability. Further, seismic activity although varies spatially, however, after 1905 Kangra earthquake, the terrain has not witnessed a major earthquake which is impending implying that the region lies in the seismic Gap (Khattri and Tyagi 1983). However, numerous tremors of less to moderate magnitude are observed every year in the region, showing that the area is seismically active (Paul et al. 2019). In view of this, it is pertinent to assess the terrain vulnerability for the safety and security of the local inhabitants particularly the threat posed by the growing incidences of landslides in the Himalayan region for which many studies have been initiated in the recent times (Sundriyal et.al., 2015; Kundu et al., 2017; Kumar et al., 2017; Sah et al., 2018; Sharma and Mahajan 2018). The preset study is in continuation of such efforts to assess the slope sensitivity and the causes of slope instability in the Giri Watershed (GW) which is considered to be one of the most landslide prone watershed in the region. The objective is to determine the Landslides Susceptibility (LS) of the GW in order to map the landslide-prone areas along with suggesting some preventive measures.

\section{Study area}

The Giri River is one of the major tributaries of Yamuna River which originates at Kupper near Shimla. It has a watershed area of $2625 \mathrm{~km}^{2}$ covering Shimla and Sirmour districts. Along its course the river is joined by multiple tributaries such as Jalal River, Aasan River, Baseri River, Choti Nadi before the Giri river meet the Yamuna river near Ponta Sahib (Fig.1). The Giri River supports irrigation for the farming in the region and there is a proposal for the Renuka hydropower project. The GW lies between latitudes $30^{\circ} 26^{\prime} 29^{\prime \prime} \mathrm{N}$ to $31^{\circ} 15^{\prime} 9^{\prime \prime} \mathrm{N}$ and longitudes $77^{\circ} 22^{\prime} 35^{\prime \prime} \mathrm{N}$ to $30^{\circ} 43^{\prime} 49^{\prime \prime} \mathrm{N}$ (Fig.1). Elevation ranges from $404 \mathrm{~m}$ to $3620 \mathrm{~m}$. The major of aspects of the slopes ranging from south to southwest thus receives adequate insolation during day and hence fairly vegetated. Due to the topographic variability the climate ranges from subtropical in the valleys and becomes temperate in the higher reaches. The Average annual rainfall based on 37 years Indian Metrological Station data during 1980-2017 spread over the GW is $1040 \mathrm{~mm}$ out of which around $80 \%$ occur during Indian Summer Monsoon (June to September).

The lithology of GW (Fig 2) comprises rocks belonging to Siwalik (Outer Himalaya), Lesser Himalayan metasedimentary and higher Himalayan Crystalline. These are separated by the 
Main Boundary Thrust (MBT) and Main Central Thrust (MCT). Besides this, the subisidiary Jutogh Thrust (JT) and Chail Thrust (CT) traverses through (right about the rocks). The outer Himalayan lithology is dominated by Subathu sand stone shaleand limestone (Mathur 1980) while Siwalik group rocks are dominated by sandstones and clays (Thakur 1992).The lesser
Himalayan sequence in $\mathrm{GW}$ is made up of conglomerate, Shales, Limestoneand Dolomite(Srikantia and Sharma 1971; Auden, 1934;Saklani 1971; Jain 1971; Thakur 1992). The Higher Himalayan Crystalline rocks includes gneisses, phyllite, limestone, metavolcanics, quartzite and granite (Thakur 1992).

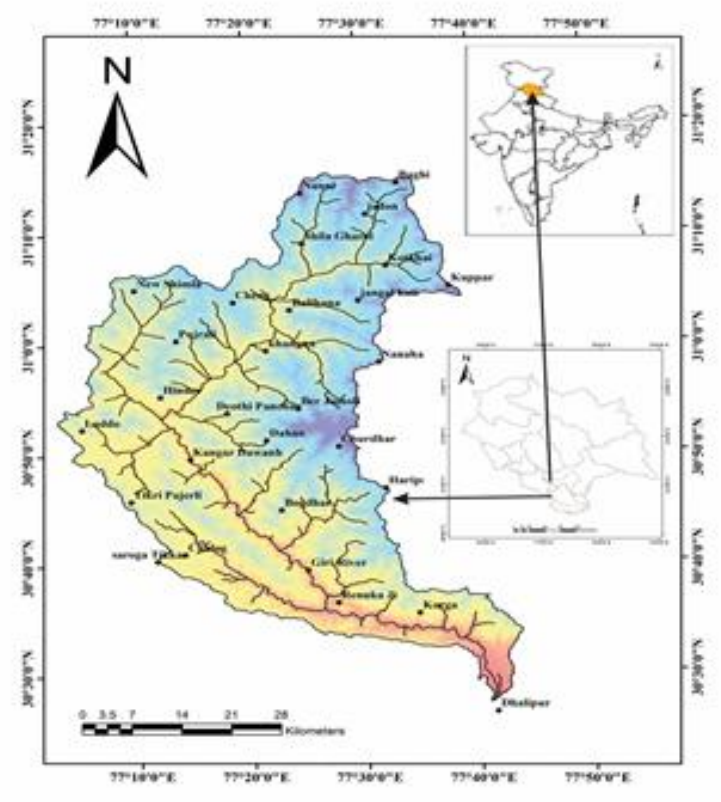

Fig 1

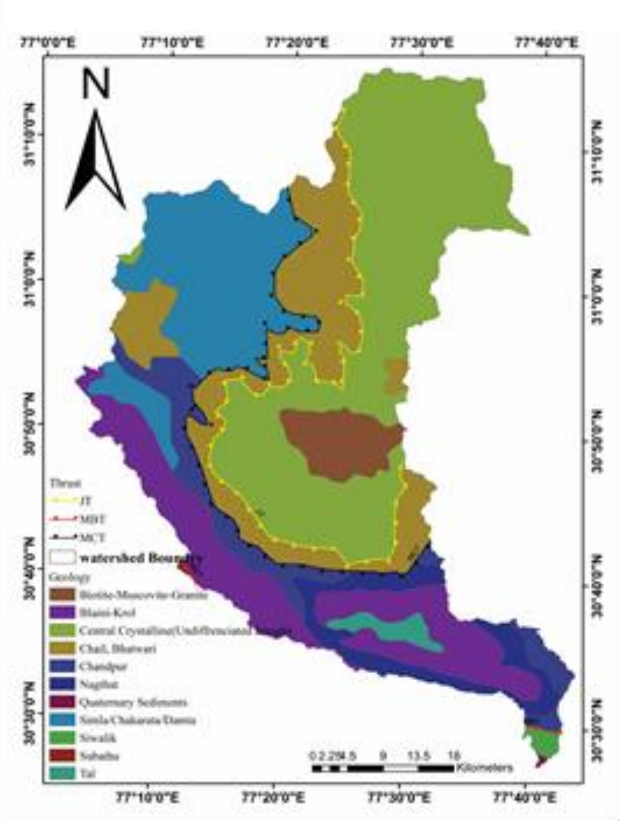

Fig 2

Fig 1: The map showing the Giri Watersheds along with major settlements. (Inset are the location of the Study area with respect to India and Himanchal Pradesh.

Fig 2: Broadly geological and major structural details of the Giri Watershed. Note that the watershed encompasses rocks of Higher Himalayan Crystalline in the north and the Siwalik sedimentary succession in the south (modified after Thakur and Rawat 1992).

\section{Database and Methodology}

We used satellite remote sensing data to demarcate the watershed boundaries. In order to asses and evaluate the susceptibility of the region, ten major factors which influence the slope instability, viz, geology, land cover, slope, aspect, curvature, elevations, proximity to lineaments, proximity to Thrust, proximity to road, and proximity to drainage (Fig 4) were analyzed. The database is created in raster format of $15 \times 15 \mathrm{~m}$ cell size of all conditioning factors using ArcGIS 10.3 tool. The slope, aspects (Fig 3), curvature, elevations (Fig 4), and drainage (Fig 7) maps are prepared using from SRTM (Shuttle Radar Topography Mission) DEM (Digital Elevation Model) of $30 \mathrm{~m}$ resolution. The drainages was further referenced with the survey of India (SOI) toposheet numbering 53E/4,7,8,11,12, and 
$53 \mathrm{~F} / 1,2,5,6,7,9,10,11$ with $1: 50,000$ scale and on Google earth. Landcover map (Fig 5) was prepared from centinal-2 image of $10 \mathrm{~m}$ resolution. The lithology and structural maps (Fig 2) are prepared from published data (Thakur and Rawat1992). Lineaments Map (Fig 8) has been prepared from centinel-2 image and Google Earth Image. The road and landslides have been digitized from SOI toposheet and Google Earth

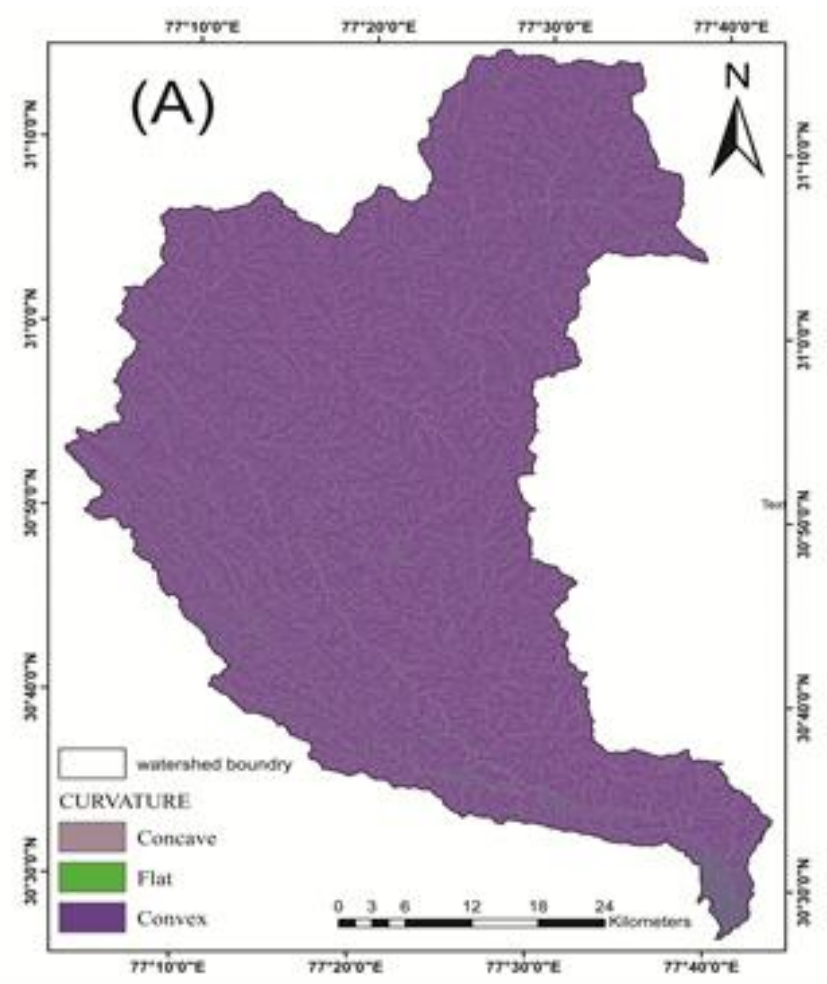

Fig 3: Map of causative factor (A) Curvature, (B) Elevations,
Image, a total of 710 major landslides were marked with the help of centinel-2 and in Google Earth, while after field validations of landslides 642 landslides were finally left since during fieldwork it was observed that many dumping zones were also marked as landslides which after fieldwork have been removed from final inventory map of landslides (Fig 6).

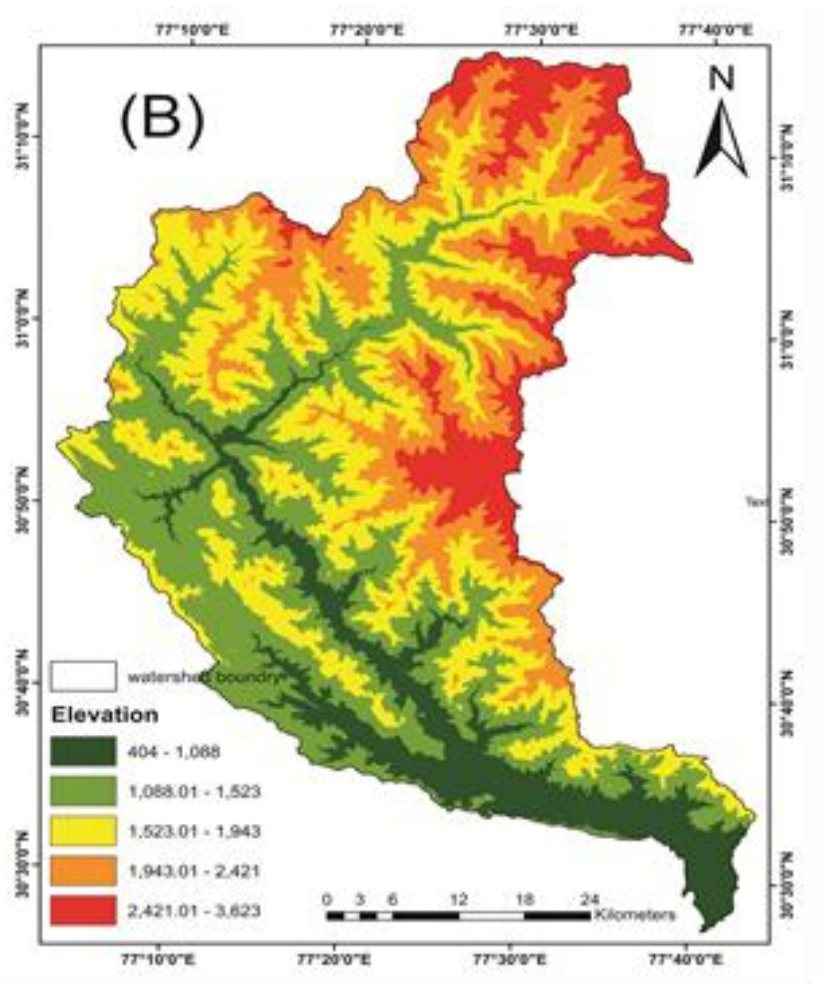



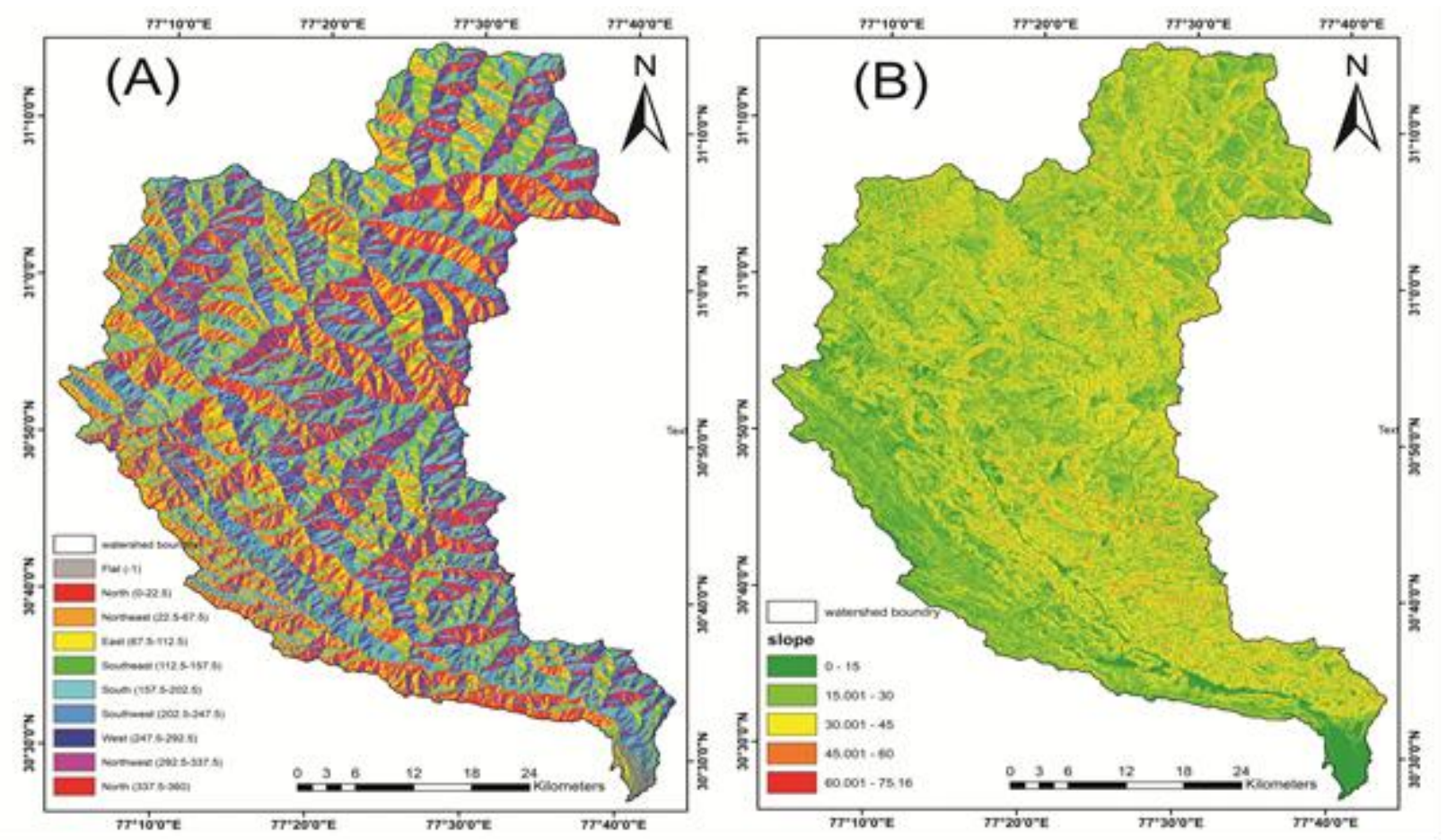

Fig 4: Causative factor map (A) Aspect, (B) Slope map
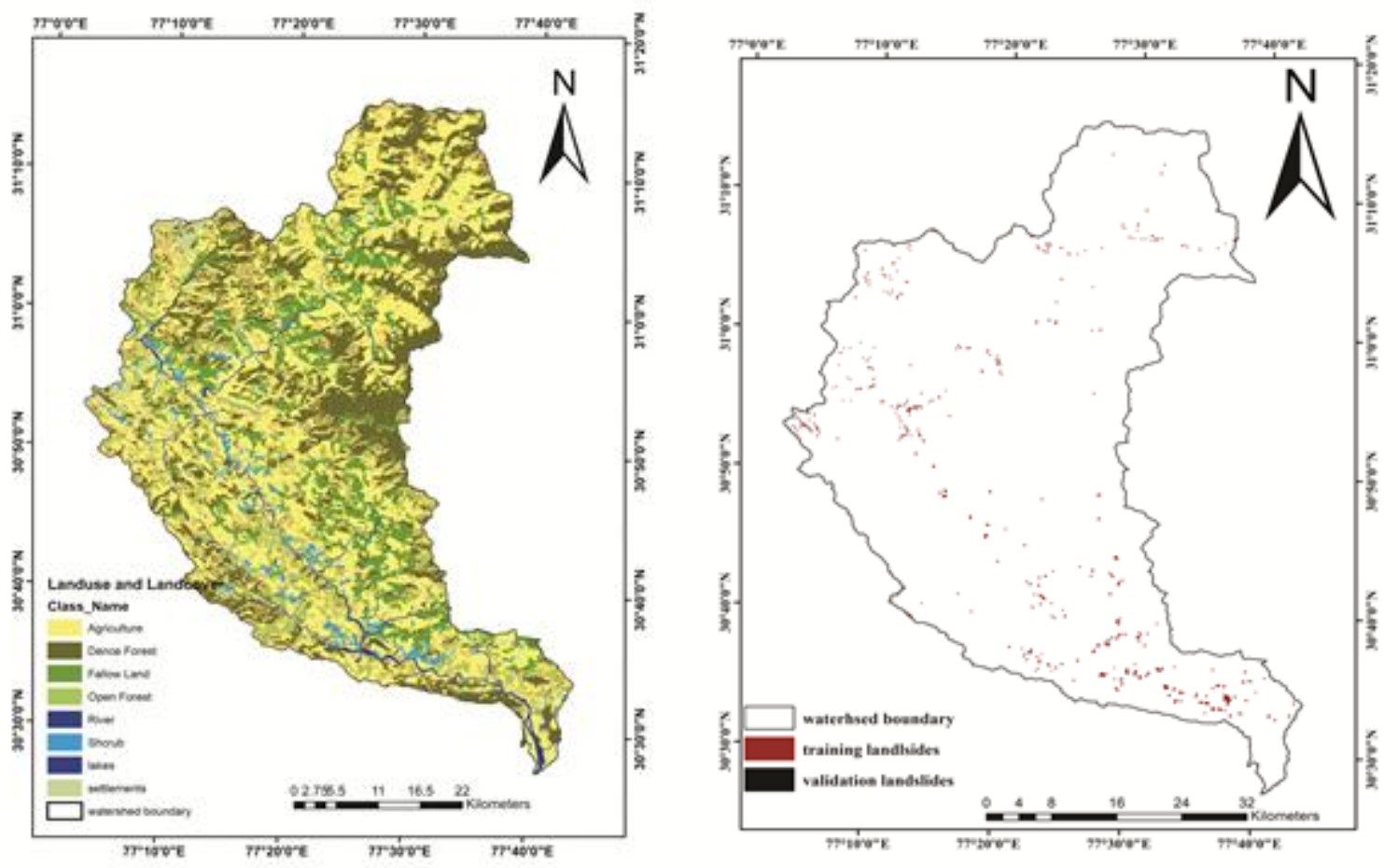

Fig 5

Fig 6

Fig 5: LULC map of GW prepared using Centinal-2 satellite image Fig 6: Landslide inventory Map prepared using Centinal- 2 satellite image and Google earth. 


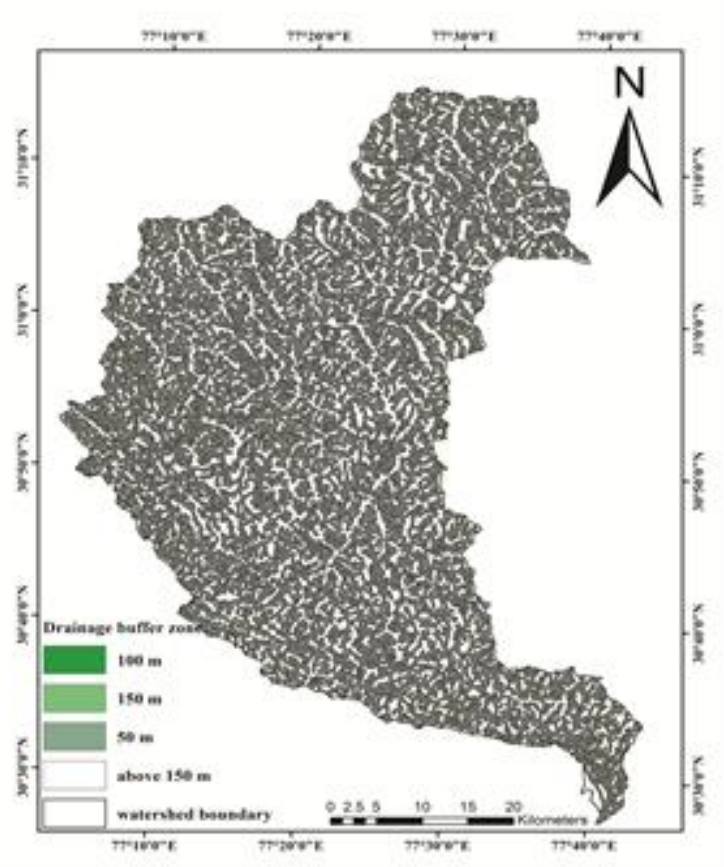

Fig 7

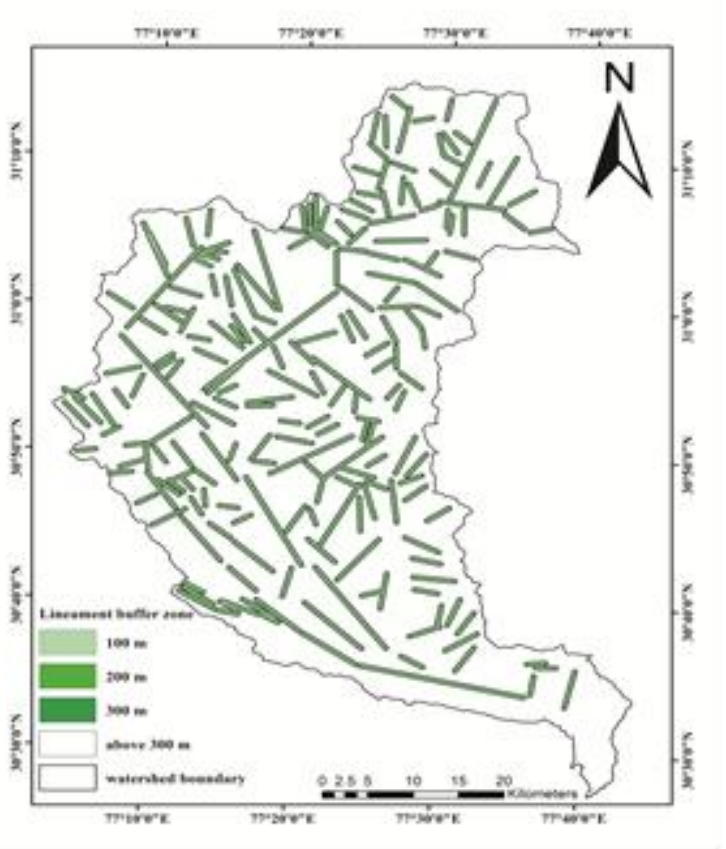

Fig 8

Fig 7: drainage buffer map of GW used as causative factor for LS mapping Fig 8: Lineament map of GW prepared from Centinal-2 imageries

\section{Landslide inventory}

Landslide inventory map (Fig6) is prepared using $10 \mathrm{~m}$ resolution Centinal-2 image aided with Google Earth, followed by field validation. Total 642 landslides were considered and digitized which have been divided into two datasets as 449 landslides in the training dataset (70\%) and 193 landslides in the validation dataset (30\%) based on random selection. Landslides inventory map was converted into a raster of $15 \times 15$ meter size which has converted the training dataset of landslides into a total of 10745 pixels. Landslides have covered a total area of $2.934746 \mathrm{~km}^{2}$. During the field visit, it was observed that maximum landslide was found in lower GW of larger size while in upper watershed some small size landslides on moderate to steep slope. Maximum landslides in GW have been observed proximal to the streams and roads. 


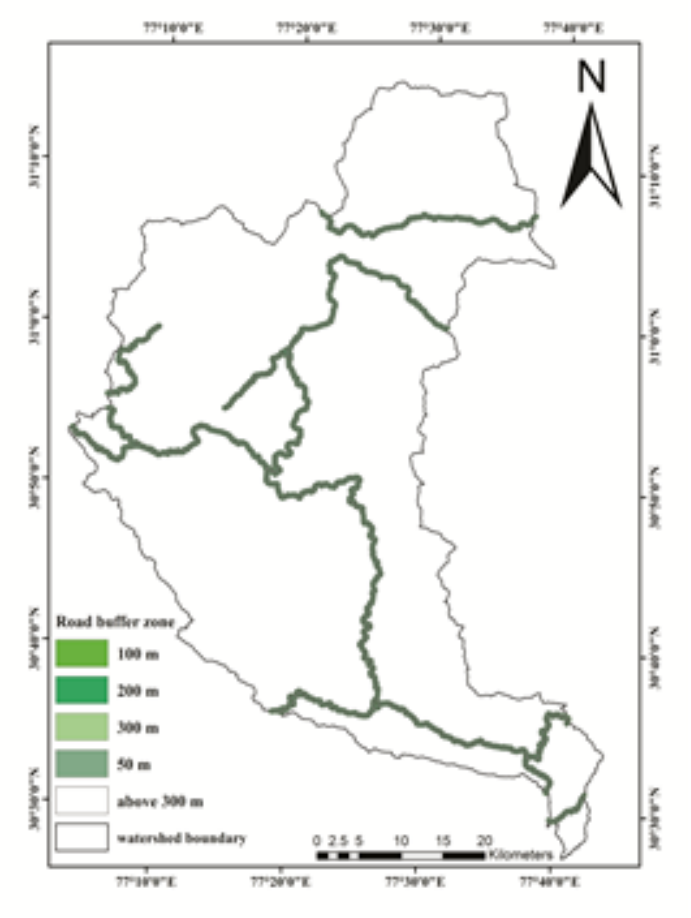

Fig 9

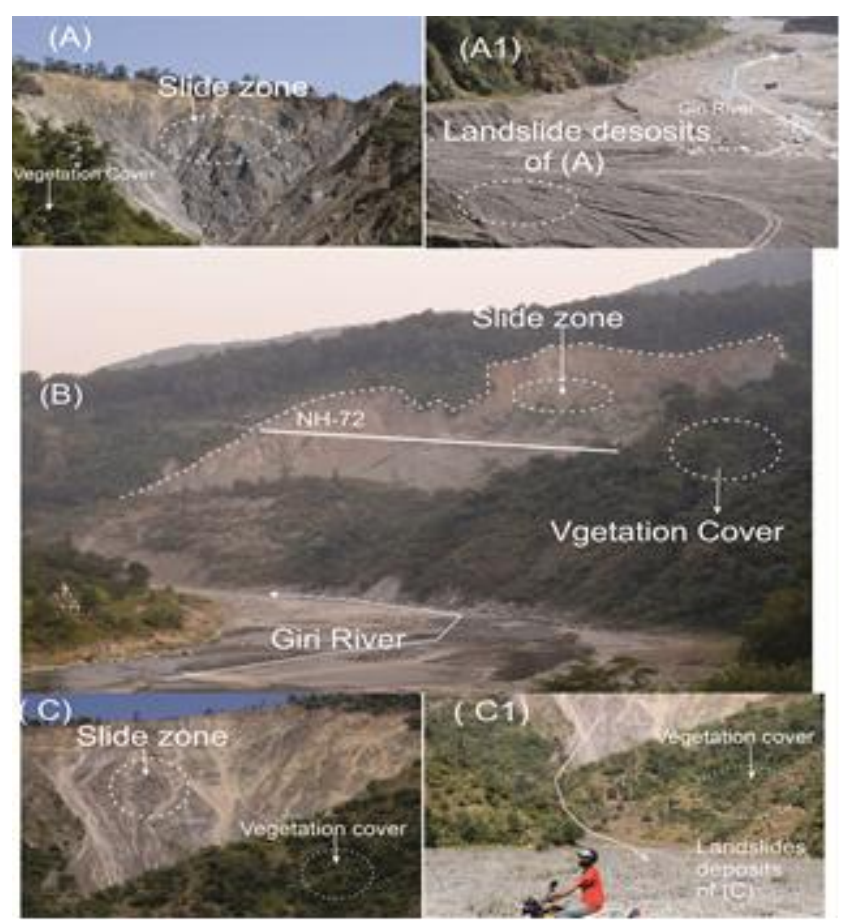

Fig 10

Fig 9: Road buffer map of GW, different buffer zone shown by different color scheme

Fig 10: GW Field photograph showing some of the landslides inblaini-krol units (A1) and (A2) are the landslides are along Satuan and Renukaji road, (B) Landslides between Rajban and Satuan, (C) and (C1) landslides near Chandani (near Renukaji).

\section{Landslide Susceptibility Mapping}

There are quantitative, semi-quantitative and qualitative methods used for LS mapping. Quantitative approach includes the Statistical, Determination, Probability and Artificial intelligence approaches. Statistical approach includes the Bivariate Statistical and Multivariate Statistical approach. Bivariate Statistical approach (BSA) includes three methods (Frequency ratio, Information value and weight of evidence), BSA rest on analytical logic, this approach is based on the premises that "past and present are the best key for future" (Dai and Lee 2001; Shano et.al. 2020). In the present study we used BSA which is based on inductive logic that suggests that "if the situation in all observed cases than the situation holds in all the cases" (Shano et.al. 2020). There are many those have applied the probabilistic model approach in a different part of the world (Lee et al. 2004; Pradhan and Lee 2010; Yalcin et al. 2011; Mohammady et al. 2012; Sharma and Mahajan 2018; Samanta et.al. 2018; Silalahi et.al.2019). 

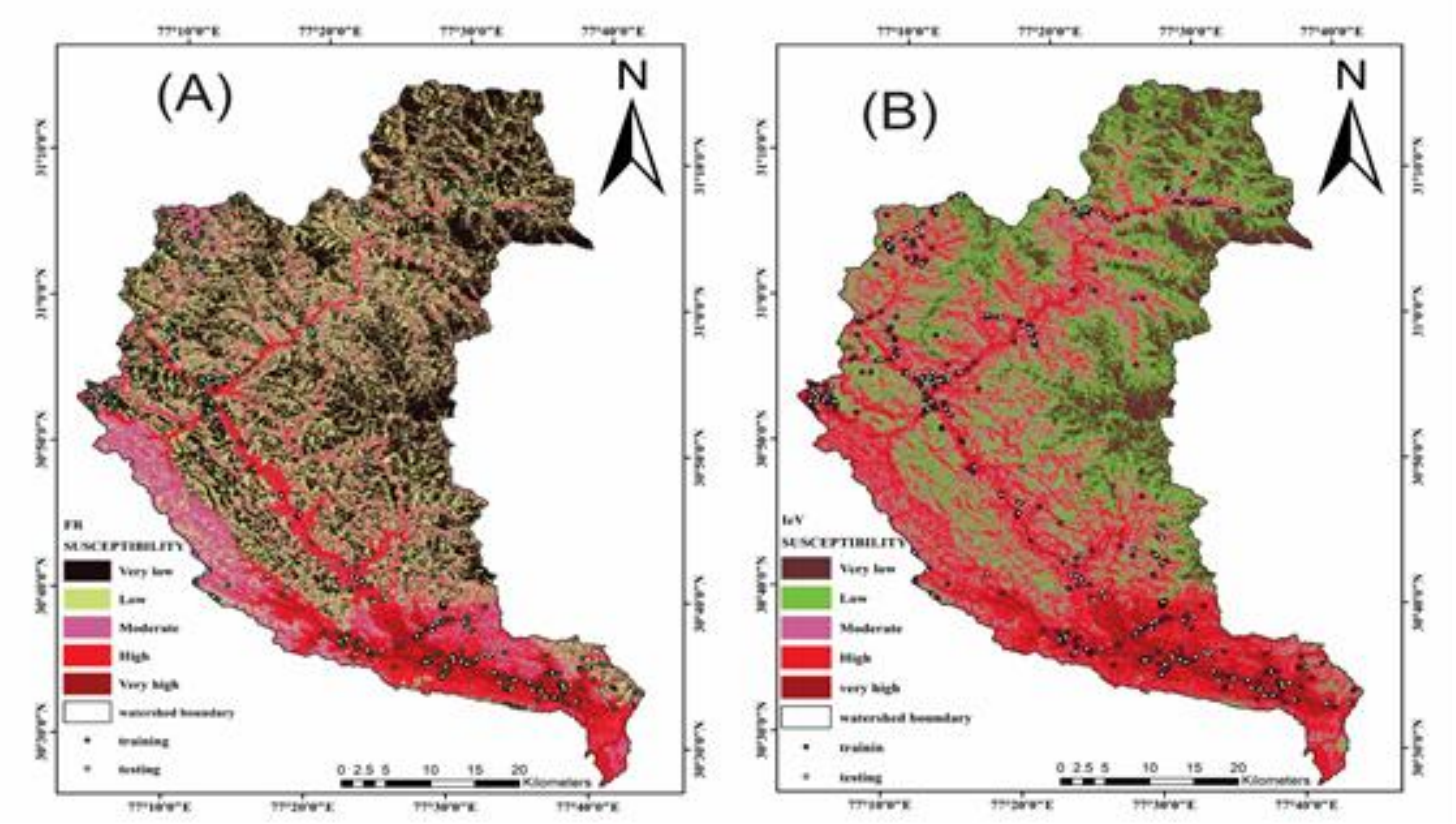

Fig 11: landslides susceptibility map prepared by (A) FR method, and (B) IeV method for GW.

The LS maps are prepared using Frequency Ratio and Information value methods. The LS maps thus generated were validated using under area curve (AUC), in AUC the success rate curve (SRC) and prediction rate curve (PRC) for both the methods were perform to see the consistency of the LS maps obtained (Fig 12).

\section{Frequency Ratio (FR)}

FR is the correlation between landslides occurrence and the causative factor employed in the analysis (Lee and Talib 2005; Ramesh and Anbazhagan 2015; Balamurgan et.al. 2016). FR can be enumerate using equation (1) and calculation of LSI (Landslide Susceptibility Index) by equation (4).

$$
\mathbf{F R}=\frac{\text { slide ratio }}{\text { Class ratio }}(1)
$$

Where Slide

ratio

Number of landslides pixel in the each subclass Total number of landslides pixel

Class ratio $=\frac{\text { Number of pixel in each subclass }}{\text { Total number of pixel in all subclass }}(3)$

$\mathbf{L S I}_{\mathrm{FR}}=\mathbf{F}_{\mathbf{1}}+\mathrm{F}_{\mathbf{2}}+\mathrm{F}_{\mathbf{3}}+\ldots \ldots \ldots \ldots \mathrm{F}_{\mathbf{n}}(4)$

Where $\mathbf{F}_{\mathbf{1}}, \mathbf{F}_{2} \ldots . . . . . . . . . . \mathbf{F}_{\text {nare }}$ the causative factor map which were reclassified according to their respective FR values. FR value less than 1 indicates the lower correlation with that causative factor and value greater than 1 indicate the high correlation with that class. 

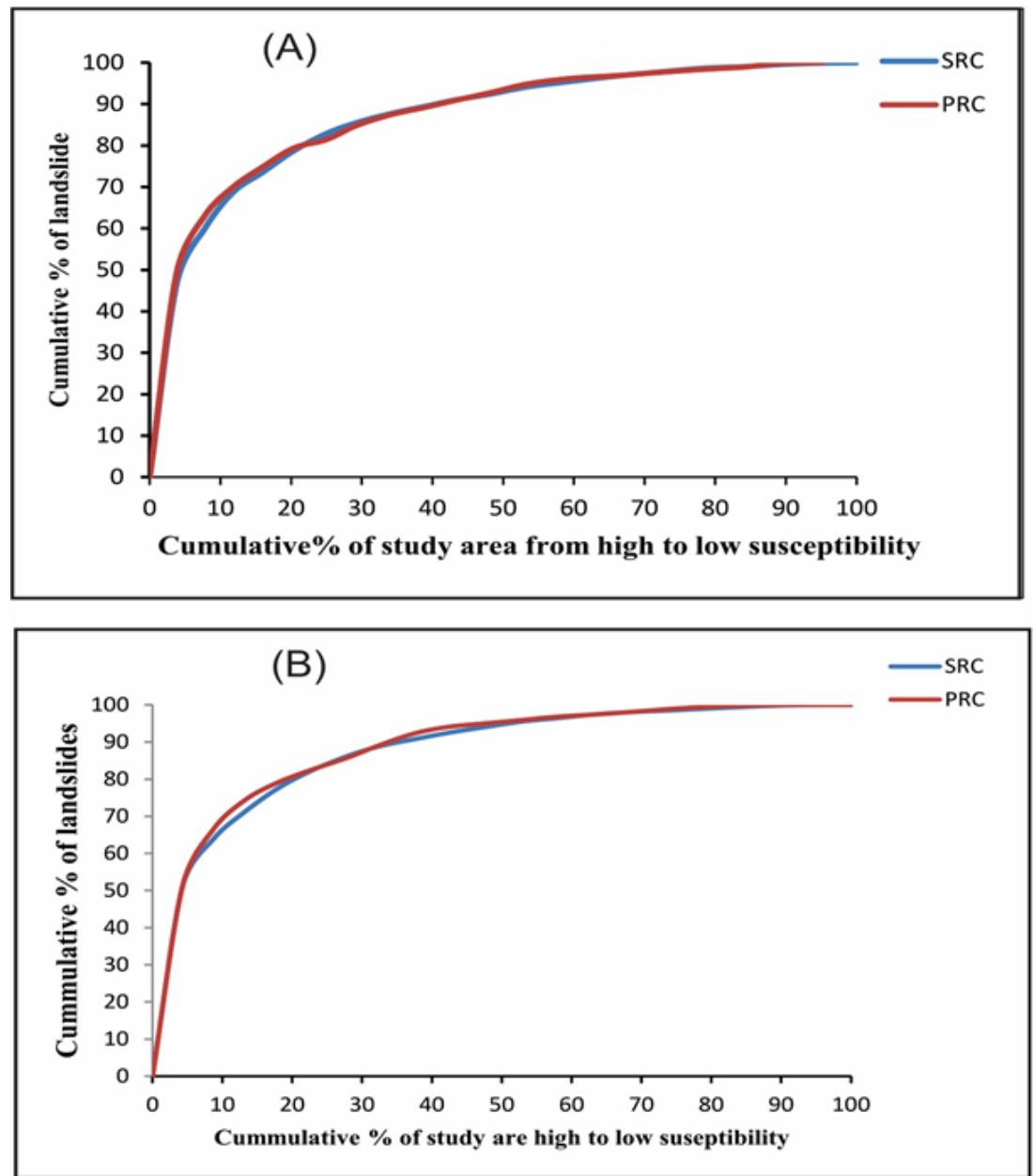

Fig 12: AUC for FR and IeV methods showing SRC (blue line) and PRC (red line) revealing interpretation for fitness of the LS methods, (A) for FR method, and (B) for IeV

\section{Information Value (IeV)}

The method ascertains the landslides potential area (Yin and Yan1988; Van Westen 1993). The method employs calculation of landslides pixel and causative factor (Sharma and Mahajan 2018). The negative value of $\mathrm{IeV}$ represent the low and negative correlations of causative factor and positive value represents the strong and positive correlation (Van westen et. al. 1997; Shano et. al. 2020). IeV is calculated using equation (5) and landslide susceptibility index (LSI) through equation (6).

$\mathbf{I e V}=\Sigma \log \left[\frac{M i / M}{N i / N}\right](5)$

$\mathbf{L S I}_{\mathrm{IeV}}=\mathrm{X}_{1}+\mathrm{X}_{2}+\mathrm{X}_{3}+\ldots \ldots \ldots \ldots \mathrm{X}_{\mathrm{n}}$
Where $\mathrm{Mi} / \mathrm{M}$ is the ratio of landslides pixel per class to the total landslides pixel and $\mathrm{Ni} / \mathrm{N}$ is the ratio of pixel of causative factor class to the total pixel of causative factor. The $\mathrm{X}$ in the equation (6) is reclassified causative factor map according to their IeVvalue.

\section{Results and discussion}

\section{Application of frequency FR}

The final susceptibility maps (Fig11) are prepared in ArcGIS 10.3 using equation (1) and (4). The map is dived into five classes of susceptibility (i) very high, (ii) high, (iii) moderate, (iv) low and (v) very low. Higher value of FR indicates the 
strong association of landslides to the causative factor class, the calculation of FR method is given in the table 1. It has been observed that the highest FR value is associated with Road buffer $(\sim 50 \mathrm{~m}$ from the road) (Table 1) and is inversely proportional to the increase in buffer beyond $50 \mathrm{~m}$ (Fig 9). Road in Himalayan terrain are considered as one of the important causative factors in triggering slope instability if care is not taken for the inherent fragile geology, unstable alluvium and nature and type of vegetation cover (Fig 10). Further, we observed that the lower valleys (400 to $1080 \mathrm{~m}$ ) showed a significant correlation with the landslides FR value (Table 1) implying that the slopes below $1080 \mathrm{~m}$ are more susceptible to slope destabilization. Similarly, compared to the tributary valleys, the trunk valley (Giri river) shows high correlation with landslides frequency (Table 1). Lithology exerts first order control due to spatial variability in the lithology which in turn influence the slope stability due to different strength parameter and density of discontinuity which leads to the different degree of susceptibility to landslides. The geological formation associated with the Tal, Subathu, Blaini-Krol, and Nagthat units show higher correlation to the landslide frequency (FR value as 4.56, 3.95, 3.28, and 1.24; Table 1). There seems to be a good correlation between the degree of slope and frequency of landslides. It has been observed that the slopes of $45^{\circ}-60^{\circ}$ has low FR value (1.44) whereas as it increases to 3.77 on $60^{\circ}-75^{\circ}$. Similarly, the slope aspect also seems to have some influence on the LS as a good correlation is observed on slopes trending South, Southwest and West (FR value 1.48, 1.70 and 1.5; Table 1). Curvature profile shows higher correlation with the negative curvature value i.e concave curvature have significant correlation with landslides (FR value 1.09). Land use practices and their impact on landslides in the settlement, agriculture, fellow land, river and scrubs class have higher correlation with the landslides in comparison to the other classes of land use (table 1). Similarly slopes proximal to major and minor structures (thrusts and lineaments) $\mathrm{T}$ shows high FR value with in the $200 \mathrm{~m}$ buffer (Table 1).Thus, based on FR methods, $7.75 \%$ area lies in very high LS zone, $12.65 \%$ area in the high, $23 \%$ in moderate, $29 \%$ in the low, and $27.5 \%$ area in the very low class of susceptibility zone (Fig 11).

\section{Application of information value (IeV) methods}

The IeV methods have been applied for the selected ten causative factors for analysis and evaluation of LS map for the GW using equation (5) and (6). All the used causative factors and their IeV value are listed in the table 1 and the susceptibility map is shown in the Fig 11. Around $47 \%$ of landslides pixels are found in the BlainiKrol unit having $\mathrm{IeV}$ as 0.5 showing strong correlation with landslides. The Subathu, Tal, and Nagthat units have $0.60,0.7$, and $0.1 \mathrm{IeV}$ respectively showing a good association with landslides. Chail, Jutogh, Simla, Chor Granite, and Chandpur units have relatively negative correlation with the landslides, (table 1). According to the slope classes division, the $45^{\circ}-60^{\circ}(0.16)$ and $60^{\circ}-75^{\circ}(0.6)$ class shows high correlation in comparison to other classes of slope. Slope aspect classes i.e South, Southwest, and West indicate higher correlation showing IeV $0.17,0.23$, and 0.06 respectively. While other classes of slope directions indicate comparatively lower association with landslides in the GW (table 1). Concave class (52\% of landslides pixel) of curvature thematic layer indicate strong correlation with landslides in comparison to flat (3\% pixel of landslides) and convex (46\% of landslides pixel falls in this class) classes according to IeV (table 1). Elevation class $404 \mathrm{~m}$ $1088 \mathrm{~m}(0.7 \mathrm{IeV}$ and $62 \%$ of landslides pixel falls in this class) class indicate higher value of $\mathrm{IeV}$ and good association with landslides in differentiation of other elevation classes. The 
impact of LULC classes show strong correlation with the agriculture, settlements, fallow land, river and scrubs while as expected a weak correlation is observed with dense forest (table 1). Similar to FR, a strong association of landslides within buffer of $50 \mathrm{~m}$ (0.78) which decrease as the distance of road buffer increases (e.g., $100 \mathrm{~m}$; $0.60,200 \mathrm{~m} ; 0.4$, and $300 \mathrm{~m} ; 0.30)$. Whereas above $300 \mathrm{~m}$ it is negative (-0.06). The lineaments buffer zone shows strong correlations with all classes except the above $300 \mathrm{~m}$ buffer zone the $\mathrm{IeV}$ (Table 1). The drainage network of GW has strong correlation with the buffer zone of the above $150 \mathrm{~m}$ showing IeV of 0.35 . The final LS map (Fig 11) obtained through the $\mathrm{IeV}$ method reveals $31 \%$ area in very low zone, $31 \%$ area in low zone, $20 \%$ area in moderate zone, $9 \%$ area in high zone, and $9 \%$ area in very high zone of LS.

Table 1: Showing results obtained from FR and IeV methods

\begin{tabular}{|c|c|c|c|c|c|c|}
\hline Causative factors & $\begin{array}{l}\text { No. of } \\
\text { landslides } \\
\text { pixel }\end{array}$ & $\begin{array}{l}\text { No of class } \\
\text { pixel }\end{array}$ & $\begin{array}{l}\text { Slide } \\
\text { Ratio }\end{array}$ & $\begin{array}{l}\text { Class } \\
\text { Ratio }\end{array}$ & FR & $\mathbf{I e V}$ \\
\hline \multicolumn{7}{|l|}{ Geology } \\
\hline Central & 1646 & 4046374 & 0.16 & 0.35 & 0.45 & -0.35 \\
\hline \multicolumn{7}{|l|}{ Crystalline(Undifferentiated } \\
\hline \multicolumn{7}{|l|}{ Jutogh) } \\
\hline Chail, Bhatwari & 1208 & 2033267 & 0.11 & 0.17 & 0.65 & -0.18 \\
\hline Simla/Chakarata/Damta & 1170 & 1913370 & 0.11 & 0.16 & 0.67 & -0.17 \\
\hline Biotite-Muscovite-Granite & 159 & 457668 & 0.02 & 0.04 & 0.38 & -0.42 \\
\hline Chandpur & 308 & 742495 & 0.03 & 0.06 & 0.46 & -0.34 \\
\hline Subathu & 24 & 6685 & 0.00 & 0.00 & 3.95 & 0.60 \\
\hline Tal & 594 & 143499 & 0.06 & 0.01 & 4.56 & 0.66 \\
\hline Blaini-Krol & 4963 & 1663287 & 0.47 & 0.14 & 3.28 & 0.52 \\
\hline Nagthat & 673 & 597794 & 0.06 & 0.05 & 1.24 & 0.09 \\
\hline Siwalik & 0 & 54553 & 0.00 & 0.00 & 0.00 & 0.00 \\
\hline Quaternary sediments & 0 & 5784 & 0.00 & 0.00 & 0.00 & 0.00 \\
\hline \multicolumn{7}{|l|}{ Slope } \\
\hline $0^{\circ}-15^{\circ}$ & 216 & 1480071 & 0.02 & 0.13 & 0.16 & -0.79 \\
\hline $15^{\circ}-30^{\circ}$ & 1194 & 3021017 & 0.11 & 0.26 & 0.43 & -0.36 \\
\hline $30^{\circ}-45^{\circ}$ & 2122 & 3410391 & 0.20 & 0.29 & 0.68 & -0.16 \\
\hline $45^{\circ}-60^{\circ}$ & 3508 & 2672167 & 0.33 & 0.23 & 1.44 & 0.16 \\
\hline $60^{\circ}-75^{\circ}$ & 3705 & 1081130 & 0.35 & 0.09 & 3.77 & 0.58 \\
\hline \multicolumn{7}{|l|}{ Aspect } \\
\hline Flate & 0 & 2259 & 0.00 & 0.00 & 0.00 & 0.00 \\
\hline North & 1000 & 1440461 & 0.09 & 0.12 & 0.76 & -0.12 \\
\hline Northeast & 772 & 1460224 & 0.07 & 0.13 & 0.58 & -0.24 \\
\hline East & 770 & 1371187 & 0.07 & 0.12 & 0.62 & -0.21 \\
\hline Southeast & 1113 & 1363498 & 0.11 & 0.12 & 0.90 & -0.05 \\
\hline South & 2150 & 1601673 & 0.20 & 0.14 & 1.48 & 0.17 \\
\hline Southwest & 2712 & 1751886 & 0.26 & 0.15 & 1.70 & 0.23 \\
\hline West & 1501 & 1441428 & 0.14 & 0.12 & 1.15 & 0.06 \\
\hline
\end{tabular}


J. Mountain Res. P-ISSN: 0974-3030, E-ISSN: 2582-5011

Vol. 16(1), (2021), 45-59

DOI: https://doi.org/10.51220/jmr.v16il.5

\begin{tabular}{|c|c|c|c|c|c|c|}
\hline Northwest & 727 & 1232160 & 0.07 & 0.11 & 0.65 & -0.19 \\
\hline \multicolumn{7}{|l|}{ Curvature } \\
\hline Concave & 5549 & 5597439 & 0.52 & 0.48 & 1.09 & 0.04 \\
\hline Flat & 283 & 461516 & 0.03 & 0.04 & 0.67 & -0.17 \\
\hline Convex & 4913 & 5605821 & 0.46 & 0.48 & 0.96 & -0.02 \\
\hline \multicolumn{7}{|l|}{ Elevation } \\
\hline 404-1088 & 6597 & 1470043 & 0.62 & 0.13 & 4.94 & 0.69 \\
\hline 1088-1523 & 2174 & 3362018 & 0.21 & 0.29 & 0.71 & -0.15 \\
\hline $1523-1943$ & 1725 & 3231439 & 0.16 & 0.28 & 0.59 & -0.23 \\
\hline 1943-2421 & 191 & 2390231 & 0.02 & 0.20 & 0.09 & -1.06 \\
\hline 2421-3623 & 58 & 1211045 & 0.01 & 0.10 & 0.05 & -1.28 \\
\hline \multicolumn{7}{|l|}{ LULC } \\
\hline Agriculture & 5739 & 5301747 & 0.54 & 0.45 & 1.19 & 0.08 \\
\hline Settlements & 691 & 213697 & 0.07 & 0.02 & 3.56 & 0.55 \\
\hline Dence Forest & 978 & 2793872 & 0.09 & 0.24 & 0.39 & -0.41 \\
\hline Fallow Land & 1380 & 1283491 & 0.13 & 0.11 & 1.18 & 0.07 \\
\hline Open Forest & 1024 & 1737371 & 0.10 & 0.15 & 0.65 & -0.19 \\
\hline River & 633 & 159895 & 0.06 & 0.01 & 4.36 & 0.64 \\
\hline Scrubs & 300 & 173607 & 0.03 & 0.01 & 1.90 & 0.28 \\
\hline Lakes & 0 & 1096 & 0.00 & 0.00 & 0.00 & 0.00 \\
\hline \multicolumn{7}{|c|}{ Distance to Road } \\
\hline 50 & 717 & 130527 & 0.07 & 0.01 & 6.05 & 0.78 \\
\hline 100 & 439 & 121658 & 0.04 & 0.01 & 3.97 & 0.60 \\
\hline 200 & 567 & 242070 & 0.05 & 0.02 & 2.58 & 0.41 \\
\hline 300 & 425 & 234018 & 0.04 & 0.02 & 2.00 & 0.30 \\
\hline above 300 & 8597 & 10936503 & 0.81 & 0.94 & 0.87 & -0.06 \\
\hline \multicolumn{7}{|c|}{ Distance to Thrust } \\
\hline 100 & 163 & 217391 & 0.02 & 0.02 & 0.83 & -0.08 \\
\hline 200 & 210 & 218060 & 0.02 & 0.02 & 1.06 & 0.03 \\
\hline 350 & 126 & 326456 & 0.01 & 0.03 & 0.42 & -0.37 \\
\hline 500 & 130 & 326024 & 0.01 & 0.03 & 0.44 & -0.36 \\
\hline above 500 & 10116 & 10576845 & 0.95 & 0.91 & 1.05 & 0.02 \\
\hline \multicolumn{7}{|c|}{ Distance to Lineament } \\
\hline 100 & 811 & 746988 & 0.08 & 0.06 & 1.19 & 0.08 \\
\hline 200 & 763 & 797989 & 0.07 & 0.07 & 1.05 & 0.02 \\
\hline 300 & 945 & 819942 & 0.09 & 0.07 & 1.27 & 0.10 \\
\hline above 300 & 8226 & 9299857 & 0.78 & 0.80 & 0.97 & -0.01 \\
\hline \multicolumn{7}{|c|}{ Distance to Drainage } \\
\hline 50 & 2005 & 4470176 & 0.19 & 0.38 & 0.49 & -0.31 \\
\hline 100 & 2388 & 2729385 & 0.23 & 0.23 & 0.96 & -0.02 \\
\hline 150 & 2189 & 2433651 & 0.21 & 0.21 & 0.99 & 0.00 \\
\hline above 150 & 4163 & 2031564 & 0.39 & 0.17 & 2.26 & 0.35 \\
\hline
\end{tabular}




\section{Validation}

For validation we have used the PRC and SRC. The SRC is the reckoning of accomplishments of a method that reveals the how well methods matches with the events (Silalahi et.al. 2019). To get the SRC the cumulative percentage of landslides (training data set) and LSI are plotted (Fig 12). PRC is reckoning of prediction assessment that reveals how well methods have predict the future potential area for landslides (Mezughi et.al. 2011; Silalahi et.al. 2019).Figure 7 show the PRC obtained by plotting cumulative percentage of landslides (validation data set) and cumulative percentage of LSI.From the validation AUC value obtained for FR Methods the PRC and SRC are $84 \%$ and $86 \%$ respectively, while for $\mathrm{IeV}$ methods AUC value for PRC is $87 \%$ and for SRC is $87 \%$. Obtained AUC value for both the methods are good and reasonable revealing a good results of LS mapping (Fig 12).

\section{Conclusion}

The selection of causative factors for LS mapping in Himalayan region is a challenge due to its complexity, rugged topography and extremely variable environmental setting. In light of these complexity, the satellite remote sensing data supported by the empirical relationship allowed us to ascertain the terrain susceptibility towards the slope instability (landslides). Based on the ten important factors (discussed above) following major inferences can be made.

1) The LS has been found to be maximum in the proximity of the road buffer zone of $50 \mathrm{~m}$ and $100 \mathrm{~m}$ and proximity of the slopes to the river bed.

2) Lower elevation, rocks of Tal, Blani and Subathu found to be susceptible to landslide due to the dominance of fine grains (clay and silt). In addition to this, the valley floor along the GW is being continuously modified due to mining activity which is impacting the slope instability by activating the angle of repose.

3) The study demonstrates that FR along with Ive can be used in association with the satellite remote sensing data in ArcGIS platform can help in identifying the potential area of instability. This will help in managing and mitigating the terrain instability in the geologically fragile watersheds.

\section{Acknowledgements}

The authors wish to acknowledge Gambhir Singh Chauhan and Ashish Rawat, Department of Geology, School of Earth Sciences, HNB Garhwal University Srinagar Garhwal for their help in preparing this manuscript. Authors are also thankful to blind reviewers for their suggestions and comments to improve the articles.

\section{References}

Auden, J.B., 1934. The geology of the Krol belt. Rec. Geol. Surv. India, 67(4),:.357-454.

Balamurugan, G., Ramesh, V. and Touthang, M., 2016. Landslide susceptibility zonation mapping using frequency ratio and fuzzy gamma operator models in part of $\mathrm{NH}-39$, Manipur, India. Nat. Haza., 84(1), :465-488.

Burke, K. and Dewey, J.F., 1973. Plumegenerated triple junctions: key indicators in applying plate tectonics to old rocks. The $J$. Geol, 81(4), :406-433.

Cruden, D.M. and Varnes, D.J., 1996. Landslides: investigation and mitigation.

Dai, F.C., Lee, C.F., Li, J.X.Z.W. and Xu, Z.W., 2001. Assessment of landslide susceptibility on the natural terrain of Lantau Island, Hong Kong. Env. Geol, 40(3), :381-391.

DeMets, C., Gordon, R.G., Argus, D.F. and Stein, S., 1994. Effect of recent revisions to the geomagnetic reversal time scale on estimates of current plate motions. Geophy. Res Lettere, 21(20), :2191-2194. 
Devkota, K.C., Regmi, A.D., Pourghasemi, H.R., Yoshida, K., Pradhan, B., Ryu, I.C., Dhital, M.R. and Althuwaynee, O.F., 2013. Landslide susceptibility mapping using certainty factor, index of entropy and logistic regression models in GIS and their comparison at Mugling-Narayanghat road section in Nepal Him, Nat. Hazard, 65(1), :135-165.

Dewey, J.F. and Bird, J.M., 1970. Mountain belts and the new global tectonics. J Geophy. Res., 75(14), :2625-2647.

Jain, A.K., 1971. Stratigraphy and tectonics of lesser Himalayan region of Uttarkashi, Garhwal Himalaya. Him. Geo. 1, :25-58.

Kanungo, D.P. and Sharma, S., 2014. Rainfall thresholds for prediction of shallow landslides around Chamoli-Joshimath region, Garhwal Himalayas, India. Landslides, 11(4), :629-638.

Khattri, K.M. and Tyagi, A.K., 1983. Seismicity patterns in the Himalayan plate boundary and identification of the areas of high seismic potential. Tectono., 96(3-4), :281-297.

Kumar, D., Thakur, M., Dubey, C.S. and Shukla, D.P., 2017. Landslide susceptibility mapping $\&$ prediction using support vector machine for Mandakini River Basin, Garhwal Himalaya, India. Geomor. 295, :115-125.

Kundu, J., Sarkar, K., Tripathy, A. and Singh, T.N., 2017. Qualitative stability assessment of cut slopes along the National Highway-05 around Jhakri area, Himachal Pradesh, India. J. Ear. Sys. Sci, 126(8), :1-15.

Lee, S. and Talib, J.A., 2005. Probabilistic landslide susceptibility and factor effect analysis. Env. Geo., 47(7), :982-990.

Lee, S., Ryu, J.H., Won, J.S. and Park, H.J., 2004. Determination and application of the weights for landslide susceptibility mapping using an artificial neural network. Eng. Geol, 71(3-4), :289-302.
Mathur, N.S., 1980. Biostratigraphical aspects of the Subathu Formation, Kumaun Himalaya.

Mezughi, T.H., Juhari, M.A., Abdul, G.R. and Ibrahim, A., 2011. Landslide susceptibility assessment using frequency ratio model applied to an area along the EW highway (Gerik-Jeli). American J. Env. Sci., 7(1), :4350.

Mohammady, M., Pourghasemi, H.R. and Pradhan, B., 2012. Landslide susceptibility mapping at Golestan Province, Iran: a comparison between frequency ratio, Dempster-Shafer, and weights-of-evidence models. Journal of Asian Earth Sciences, 61, :221-236.

Paul, A., Tiwari, A. and Upadhyay, R., 2019. Central Seismic Gap and Probable zone of large earthquake in North West Himalaya. Him. Geo., 40(2), :199-212.

Pradhan, B. and Lee, S., 2010. Landslide susceptibility assessment and factor effect analysis: backpropagation artificial neural networks and their comparison with frequency ratio and bivariate logistic regression modelling. Env. Mod. Softw., 25(6), :747-759.

Ramesh, V. and Anbazhagan, S., 2015. Landslide susceptibility mapping along Kolli hills Ghat road section (India) using frequency ratio, relative effect and fuzzy logic models. Env. Earth Sci., 73(12), :8009-8021.

Rana, N., Sati, S.P., Sundriyal, Y.P., Doval, M.M. and Juyal, N., 2007. Socio-economic and environmental implications of the hydroelectric projects in Uttarakhand Himalaya, India. J Mountain Sci, 4(4), :344353.

Sah, N., Kumar, M., Upadhyay, R. and Dutt, S., 2018. Hill slope instability of Nainital City, Kumaun Lesser Himalaya, Uttarakhand, India. Journal of rock mechanics and geotechnical engineering, 10(2), :280-289. 
Saklani, P.S., 1971. Structure and tectonics of the Pratapnagar area, Garhwal Himalaya. Him. Geol, 1, :75-91.

Samanta, R.K., Bhunia, G.S., Shit, P.K. and Pourghasemi, H.R., 2018. Flood susceptibility mapping using geospatial frequency ratio technique: a case study of Subarnarekha River Basin, India. Mod. Earth Syst. Env., 4(1), :395-408.

Sarkar, S. and Kanungo, D.P., 2004. An integrated approach for landslide susceptibility mapping using remote sensing and GIS. Photo. Eng. Rem. Sens. 70(5), :617-625.

Sati, S.P., Naithani, A. and Rawat, G.S., 1998. Landslides in the Garhwal Lesser Himalaya, UP, India. Envi., 18(3), :149-155.

Sati, S.P., Sundriyal, Y.P., Rana, N. and Dangwal, S., 2011. Recent landslides in Uttarakhand: nature's fury or human folly. Curr. Sci. (Bangalore), 100(11), :1617-1620.

Shano, L., Raghuvanshi, T.K. and Meten, M., 2020. Landslide susceptibility evaluation and hazard zonation techniques-a review. Geoenvi. Disas. 7:1-19.

Sharma, S. and Mahajan, A.K., 2018. Comparative evaluation of GIS-based landslide susceptibility mapping using statistical and heuristic approach for Dharamshala region of Kangra Valley, India. Geoenvironmental Disasters, 5(1), p.4.

Silalahi, F.E.S., Arifianti, Y. and Hidayat, F., 2019. Landslide susceptibility assessment using frequency ratio model in Bogor, West Java, Indonesia. Geosci. Letters, 6(1), :1-17.

Singh, S.K., Mohanty, W.K., Bansal, B.K. and Roonwal, G.S., 2002. Ground motion in Delhi from future large/great earthquakes in the central seismic gap of the Himalayan arc. Bull. Seis. Scoi Amer., 92(2), :555-569.

Srikantia, S.V. and Sharma, R.P., 1971. Simla Group-A Reclassification of the'Chail Series"Jaunsar Series' and'Simla Slates' in the
Simla Himalaya. Geol. Soc. India, 12(3), :234-240.

Sundriyal, Y.P., Shukla, A.D., Rana, N., Jayangondaperumal, R., Srivastava, P., Chamyal, L.S., Sati, S.P. and Juyal, N., 2015. Terrain response to the extreme rainfall event of June 2013: Evidence from the Alaknanda and Mandakini River Valleys, Garhwal Himalaya, India. Episodes, 38(3), :179-188.

Thakur, V.C. and Rawat, B.S., 1992. Geological map of the Western Himalaya. Published under the authority of the Surveyor General of India. Printing Group of Survey of India, 101

Thakur, V.C., 1992. Geology of western Himalaya. Phy. Chem. Earth, 19, :1-355.

Van Westen, C.J., (1993). Application of geographic information systems to landslide hazard zonation. Ph.D. Thesis (90-6164-0784).http://www.itc.nl/library/Papers_1993/ phd/vanwesten.pdf

Van Westen, C.J., Rengers, N., Terlien, M.T.J. and Soeters, R., 1997. Prediction of the occurrence of slope instability phenomenal through GIS-based hazard zonation. Geol. Rundschau, 86(2):404-414.

Yalcin, A., Reis, S., Aydinoglu, A.C. and Yomralioglu, T., 2011. A GIS-based comparative study of frequency ratio, analytical hierarchy process, bivariate statistics and logistics regression methods for landslide susceptibility mapping in Trabzon, NE Turkey. Catena, 85(3), :274-287.

Yin, A., 2006. Cenozoic tectonic evolution of the Himalayan orogen as constrained by alongstrike variation of structural geometry, exhumation history, and foreland sedimentation. Earth-Sci.Revi, 76(1-2):1-31.

Yin, K.L. and Yan, T.Z., 1988. Statistical prediction models for instability of metamorphosed rocks. In International symposium on landslides. $5: 1269-1272$.

******* 